\title{
STATE POLICY CONCERNING RUSSIAN ORTHODOX CHURCH BETWEEN 1958 AND 1964 (BASED ON KRASNODAR KRAI)
}

\author{
Natalia Yu. Belikova \\ Kuban State Technological University, Krasnodar, Russian Federation
}

\begin{abstract}
Introduction. The article is devoted to the problem of revealing the consequences of state religious policy in the region under study in the period between 1958 and 1964. The initial date is associated with the end of the post-Stalin struggle for leadership in the Communist party and the state and the formation of a new Church policy aimed at the destruction of religious organizations in the USSR. The end of the period is associated with the change of the top leadership of the USSR and the attendant changes in religious policy. In order to identify the consequences of state religious policy, the author analyzes the nature and content of this policy, as well as the attitude of believers to the anti-church actions of local authorities. The territory of the Krasnodar and Kuban dioceses in the period under study corresponded to the administrative borders of Krasnodar Krai. This diocese was headed by Metropolitan Viktor (Svyatin). Methods and materials. The use of the statistical method allowed the author to reveal the dynamics of personnel changes among the Orthodox clergy, the number of closed temples in the Krasnodar and Kuban dioceses and the number of religious ceremonies performed by the clergy. As a result of applying the system method the author reveals that not only local Soviet and party authorities took part in implementing religious policy, but also the public was actively involved that gave large-scale anti-Church actions. Analysis. The aspiration of authorities to the full replacement of the Orthodox church from life of citizens in the region under study led to the loss of more than a half of personnel structure of priests and to closing more than $50 \%$ of temples. To fight against religious traditions the government used both administrative measures expressed in changing the rules of the baptism ceremony, and distribution of experience of Soviet non-religious rites. These measures led to the fact that in the period between 1958 and 1964 the number of baptisms decreased by $38.2 \%$, weddings - by $87 \%$, funerals - by $66 \%$. However, residents of the region continued to visit churches and participate in religious ceremonies. Results. It was found that in Krasnodar Krai the rite of baptism amounted to the largest percentage compared to other rites, which indicates the greater demand for this rite among the parishioners. As a result of the state religious policy, the Orthodox Church as an institution was dealt a serious blow, but it was not possible to eliminate the religiosity of the population.
\end{abstract}

Key words: Orthodox church, Krasnodar Krai, religious policy, baptism, religious rites.

Citation. Belikova N.Yu. State Policy Concerning Russian Orthodox Church Between 1958 and 1964 (Based on Krasnodar Krai). Vestnik Volgogradskogo gosudarstvennogo universiteta. Seriya 4. Istoriya. Regionovedenie. Mezhdunarodnye otnosheniya [Science Journal of Volgograd State University. History. Area Studies. International Relations], 2019, vol. 24, no. 5, pp. 135-147. (in Russian). DOI: https://doi.org/10.15688/jvolsu4.2019.5.10

УДК 27:33(470.62)195

Дата поступления статьи: 06.08.2018

ББК $63.3(2) 623$

Дата принятия статьи: 20.01.2019

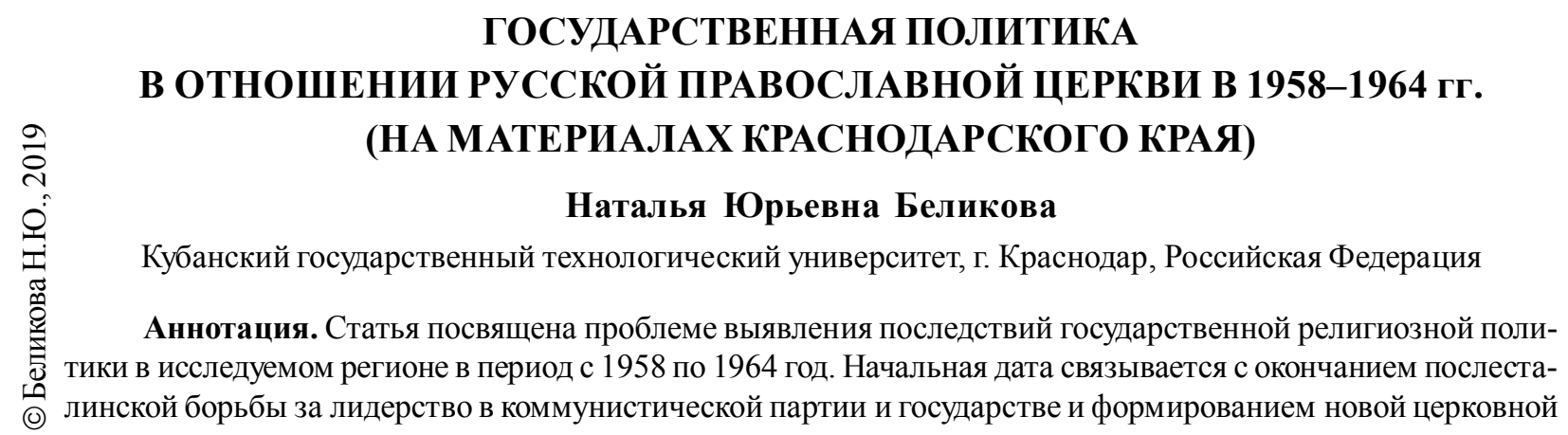


политики, направленной на разрушение религиозных организаций в СССР. Окончание периода связано со сменой высшего руководства СССР и сопутствующими изменениями в религиозной политике. С целью выявления последствий государственной религиозной политики были проанализированы характер, содержание данной политики, а также отношение верующих к антицерковным действиям местных органов власти. Территория Краснодарской и Кубанской епархии в исследуемый период соответствовала административным границам Краснодарского края. Данную епархию возглавлял митрополит Виктор (Святин). Применение статистического метода позволило автору выявить динамику изменения кадрового состава среди православного духовенства, количество закрытых храмов в Краснодарской и Кубанской епархии и количество совершаемых священнослужителями религиозных обрядов. В результате применения системного метода было выявлено, что в реализации религиозной политики принимали участие не только местные советские и партийные органы власти, но и активно привлекалась общественность, что придавало широкомасштабность антицерковным акциям. Стремление органов власти к полному вытеснению Православной церкви из жизни граждан в исследуемом регионе привело к потере более половины кадрового состава священнослужителей и закрытию более $50 \%$ храмов. Для борьбы с религиозными традициями власти использовали как административные меры, выразившиеся в изменении правил оформления документов при крещении детей, так и распространение опыта организации советских нерелигиозных обрядов. Эти меры привели к тому, что с 1958 по 1964 г. количество крещений уменьшилось на $38,2 \%$, венчаний - на $87 \%$, отпеваний - на $66 \%$. Однако жители края продолжали посещать храмы и участвовать в религиозных обрядах. Было выявлено, что в Краснодарском крае обряд крещения составлял наибольший процент в сравнении с другими обрядами, что говорит о большей востребованности данного обряда у прихожан. В результате государственной религиозной политики Православной церкви как институгу был нанесен серьезный удар, но ликвидировать религиозность населения не удалось.

Ключевые слова: Православная церковь, Краснодарский край, религиозная политика, крещение, религиозные обряды.

Цитирование. Беликова Н. Ю. Государственная политика в отношении Русской православной церкви в 1958-1964 гг. (на материалах Краснодарского края) // Вестник Волгоградского государственного университета. Серия 4, История. Регионоведение. Международные отношения. - 2019. - Т. 24, № 5. - С. 135-147. - DOI: https://doi.org/10.15688/jvolsu4.2019.5.10

Введение. Русская православная церковь (РПЦ) на сегодняшний день остается наиболее многочисленной и влиятельной религиозной организацией в Российской Федерации. Происходит переоценка роли РПЦ в развитии страны на современном этапе. Период в истории взаимоотношений государства и РПЦ с конца 1950-х - начала 1960-х гг. характеризуется активными антицерковными кампаниями. В стране в это время происходили серьезные общественно-политические перемены, связанные с либерализацией общества, а в отношении РПЦ начались новые гонения. Изучение этого периода очень важно для выстраивания новой модели взаимоотношений государства и РПЦ.

Направления государственной политики в отношении Православной церкви разрабатывались в центральных органах власти, однако ее реализация зависела от деятельности органов власти на местах. Поэтому без региональных исследований практически невозможно выявить итоги государственной религиозной политики и ее влияние на жизнь РПЦ и верующих. В этой связи актуальным явля- ется исследование религиозной политики советского государства в 1958-1964 гг. в таком регионе, как Краснодарский край, где православные традиции имеют глубокие корни.

Дискуссия. Для написания данной статьи важное значение имели работы отечественных и зарубежных ученых, посвященные вопросам взаимоотношений советского государства и РПЦ.

В работах советских исследователей до конца 1980-х гг. прослеживается негативное отношение к религии. В исследованиях А.Н. Барменкова [3], В.А. Куроедова [13] религиозные организации рассматривались как враждебная, идеологически чуждая советскому строю сила. Идеологическую основу этих исследований составляли марксистско-ленинские принципы отношения к религии. Антирелигиозная политика в СССР в трудах данных авторов объяснялась с точки зрения утвердившейся идеологии. Привлекая статистический материал о посещаемости культовых зданий, динамику сокращения обрядности, авторы доказывали успешное проведение антирелигиозной политики. 
В работе исследователя Н.С. Гордиенко «Эволюция русского православия (20-80-е гг. $\mathrm{XX}$ столетия)» рассматриваются вопросы о снижении роли православия в обществе и попытки церкви приспособиться к изменившимся социальным условиям [4]. В советской литературе говорилось об упадке религиозных практик. По мнению Н.С. Гордиенко, кризис достиг своей максимальной глубины к моменту празднования тысячелетия крещения Руси $[4$, с. 63].

С конца 80-х гг. XX в. произошли коренные изменения в изучении государственной политики в отношении РПЦ. Это связано с празднованием 1000-летия крещения Руси и новыми тенденциями в обществе в период «перестройки». Для трудов этого периода характерен плюралистический подход к научному исследованию. Одним из первых отечественных ученых, который использовал ранее закрытые архивные данные для изучения проблемы идеологического неприятия православия партийным аппаратом, стал В.А. Алексеев [1]. Однако значительное место в его исследовании «Иллюзии и догмы» уделено первой половине XX в., а хрущевский период отражен фрагментарно.

Воздействие политики государства на деятельность РПЦ можно проследить в работах М.И. Одинцова. Он систематизировал исторический опыт деятельности государственных органов, курирующих религиозные организации, в частности Совет по делам РПЦ. Ему принадлежит первенство в публикации документов Совета по делам РПЦ. Изучая религиозную политику конца 1950-х начала 1960-х гг., М.И. Одинцов приходит к выводу, что для этого периода характерно отстранение государства от проблем религиозной сферы и стремление полагаться на партийные решения. Советы по делам РПЦ, по его мнению, стали играть роль инструмента для воплощения идеологических установок партии [14]. Исследователь Г.Д. Панков, изучая религиозную политику советского государства в конце 1950-х - начале 1960-х гг., на основе архивных документов Совета по делам РПЦ выделил в особый этап взаимоотношения РПЦ и государства в эти годы. В его работе представлены примеры реализации новой политики в различных регионах страны [19].
Широко используя архивные документы Совета по делам религий при Совете Министров СССР, священнослужитель С. Гордун изучал деятельность РПЦ с 1943 по 1970 год. Его исследование было опубликовано в «Журнале Московской Патриархии». Он рассматривал вопросы противодействия духовенства и верующих государственной политике, направленной против РПЦ [5].

Историк М.В. Шкаровский предложил собственную периодизацию государственной религиозной политики 1939-1964 гг., выделив этап 1958-1964 годов. Его работа «Русская православная церковь при Сталине и Хрущеве (государственно-церковные отношения в СССР в 1939-1964 гг.)» построена на богатом фактическом материале, который позволяет характеризовать события 1958-1964 гг., как «трагический период последних попыток руководства СССР радикально, в кратчайшие сроки решить религиозную проблему в стране» $[27$, с. 359$]$. Главной причиной нового наступления на Церковь автор считает уверенность значительной части советского руководства в жизнеспособности коммунистической идеологии, которой нет, и не может быть никакой религиозной альтернативы, а также и экономические расчеты властей - пополнить «прохудившийся» бюджет за счет РПЦ [27, с. 359].

Одним из авторитетных современных историков, изучающих проблемы церковной политики эпохи «хрущевской оттепели», является Т.А. Чумаченко. В работе Т.А. Чумаченко, построенной на материалах федеральных архивов, рассматриваются причины изменения религиозной политики в отношении РПЦ в 1958-1964 гг., ее характер, содержание и результаты. По мнению Т.А. Чумаченко, антицерковная кампания Н.С. Хрущева носит характер новой политической войны с Церковью и верующими [26, с. 84].

Анализируя зарубежную историографию по исследуемой теме, следует выделить работу канадского ученого Д.В. Поспеловского «Русская православная церковь в XX веке», целая глава которой посвящена истории «хрущевских гонений» 1958-1964 годов. Главной причиной этих гонений автор считает обеспокоенность гражданских властей послевоенным оживлением церковной жизни [20, с. 280]. 
Завершая краткий обзор литературы по заявленной теме, следует сказать, что отечественные и зарубежные исследователи добились успехов в изучении государственной религиозной политики в СССР, что существенно облегчает исследование выбранной темы на региональном уровне.

Среди трудов регионального характера необходимо отметить исследование Е.Ф. Кринко «Православная церковь на Кубани в годы Великой Отечественной войны». Статья наполнена фактическим материалом, характеризующим положение РПЦ в период войны на территории Краснодарского края. Представленный в статье материал важен для выявления особенностей реализации религиозной политики государства в регионе в 1950-1960-е гг. по сравнению с военным периодом [12]. Исследователи А.В. Бабич и С.Н. Рыбко в работе «Православные приходы Советской Кубани», изучая особенности положения православных приходов в советский период, частично приводят данные о динамике изменения количества приходов в 1950-1960-е гг. ХХ в. в исследуемом регионе [2]. Следует выделить также диссертационное исследование В.В. Трегубенко «Религиозный вопрос на Ставрополье и Кубани в 1941 г. - начале 1960-х гг.: сущность, место в обществе, отношение власти» [25]. Автор на основе значительного фактического материала центральных и региональных архивов предпринял попытку создания целостной картины государственно-конфессиональных отношений в заявленных регионах. История взаимоотношений государственных органов власти и Православной церкви в Краснодарском крае в 1958-1964 гг. частично затрагивалась в диссертации М.И. Соколовой «Советское государство и Русская православная церковь в 1953-1964 гг. (на материалах Сталинградской (Волгоградской) области)» [22].

Вместе с тем период 1958-1964 гг. в истории взаимоотношений государственных органов власти и РПЦ в Краснодарском крае остается слабо изученным.

Методы. При изучении религиозной политики в отношении РПЦ использовался системный метод. С точки зрения этого метода компонентами религиозной политики являлись: РПЦ, советские и партийные органы власти, а также общественные организации. При иссле- довании динамических процессов развития православных приходов, поддающихся цифровым характеристикам, применялся статистический метод. С помощью этого метода проанализирован и приведен в систему большой статистический материал, отражающий изменения численности приходов, священнослужителей, а также количество совершаемых православной церковью религиозных треб и обрядов в Краснодарском крае в исследуемый период.

Историко-генетический метод применялся для установления причинно-следственных связей развития РПЦ и советского религиозного законодательства с 1958 по 1964 год.

Материалы. Данная статья базируется на материалах Государственного архива Краснодарского края и Центра документации новейшей истории Краснодарского края. Привлеченные архивные документы позволяют изучить основные направления государственной религиозной политики в 1958-1964 гг. и ее влияние на жизнь РПЦ и верующих в Краснодарском крае.

Анализ. Первые шаги по изменению религиозной политики власти были заложены в следующих правовых документах: 4 октября 1958 г. ЦК КПСС принял секретное постановление «О записке Отдела пропаганды и агитации ЦК КПСС по союзным республикам» «О недостатках научно-атеистической пропаганды» от 12 сентября 1958 г., предписывавшее партийным и общественным организациям и государственным органам начать наступление на «религиозные пережитки» советских людей. В постановлении Совета Министров СССР от 16 октября 1958 г. № 1160 «О налоговом обложении доходов предприятий епархиальных управлений, а также доходов монастырей» и постановлении Совета Министров СССР от 16 октября 1958 г. № 1159 «О монастырях в СССР» государственным учреждениям предписывалось осуществить мероприятия административного характера, направленные на ужесточение условий существования религиозных организаций [7, с. 35-36]. Эти документы были направлены на подрыв экономического положения религиозных объединений.

В докладе Председателю Совета по делам Русской православной церкви при Совете Министров СССР 6 августа 1958 г. Уполномоченный Совета по делам РПЦ при Совете 
Министров СССР по Краснодарскому краю С.Ф. Бабушкин сообщал, что «от продажи свечей церковь наживает колоссальные средства, так как свечной мастерской Краснодарского Епархиального управления в 1956 г. было выработано 12250 кг свечей и продано их на сумму 9188 тыс. руб., а в 1957 г. показатели увеличились - выработано 17335 кг и продано на сумму 13001 тыс. рублей. Во многих приходах РПЦ доход от продажи свечей составлял около 70 \%» [8, л. 118].

По мнению Уполномоченного, необходимо было ограничить эту материальную основу церкви законодательным актом [8, л. 119]. Увеличение налога на доходы свечных мастерских было установлено в октябре 1958 г. в результате выхода постановления Совета Министров СССР от 16 октября 1958 г. «О налоговом обложении доходов предприятий епархиальных управлений, а также доходов монастырей». С 1958 по 1959 г. наблюдалось некоторое снижение общего дохода церквей и молитвенных домов Краснодарской и Кубанской епархии. Так, в 1958 г. общий церковный доход составил 17221 тыс. руб., а в 1959 г. 16241 тыс. рублей [9, л. 31]. Необходимо отметить, что данные о церковных доходах и о количестве совершенных обрядов условны, поскольку, подавая отчеты Уполномоченному, исполнительные органы приходских церквей сознательно занижали показатели, а духовенство, выполняя «частные» требы вне стен церкви, чаще всего о них не отчитывалось.

Общий доход церквей и молитвенных домов изучаемой епархии в 1959 г. складывался из следующих статей: продажа свечей на сумму 12001 тыс. руб.; от продажи просфор поступило 1159 тыс. руб.; от продажи крестиков 376 тыс. руб.; от продажи венчиков - 131 тыс. руб.; пожертвования и прочие поступления составили сумму 2564 тыс. рублей [9, л. 32]. Таким образом, поступления от продажи свечей продолжали оставаться основной статьей дохода. Несмотря на повышение налога почти в пять раз, свечной мастерской Краснодарского Епархиального управления в 1959 г. было выработано 25665 кг свечей и продано на сумму 12001 тыс. руб. [9, л. 32], что составило $74 \%$ от общего дохода церквей и молитвенных домов Краснодарской и Кубанской епархии за 1959 год. Следует признать, что первый удар по экономическим позициям РПЦ Церковь выдержала. Это признал в 1959 г. председатель Совета по делам Русской православной церкви при Совете министров СССР Г.Г. Карпов: «...ожидавшееся некоторое ослабление экономического положения церкви в связи с постановлением Правительства о повышении налога на производство церковных свечей не произошло» [26, с. 83].

Как и в 1920-1930-е гг., с 1958 г. возобновляется закрытие храмов. К началу 1958 г. в СССР действовало 13414 зарегистрированных церквей и молитвенных домов, из них 208 - на территории Краснодарского края [8, л. 23]. С 1956 по 1958 г. на территории края храмы не закрывались, их количество сохранялось -208 , хотя, как видно из статистических данных, процесс закрытия храмов в СССР в указанные годы осуществлялся, но это были единичные случаи (табл. 1) [6, л. 36; 8, л. 23;

\section{Таблица 1. Статистические данные о количестве храмов и молитвенных домов (1956- 1965 гг.)}

Table 1. Statistics on the number of churches and prayer houses (1956-1965)

\begin{tabular}{|c|c|c|}
\hline \multirow{2}{*}{ Год } & Количество храмов и молитвенных домов на 1 января \\
\cline { 2 - 3 } & в СССР & в Краснодарском крае \\
\hline 1956 & 13417 & 208 \\
\hline 1957 & 13430 & 208 \\
\hline 1958 & 13414 & 208 \\
\hline 1959 & 13324 & 205 \\
\hline 1960 & 13008 & 202 \\
\hline 1961 & 11572 & 172 \\
\hline 1962 & 10149 & 140 \\
\hline 1963 & 8580 & 109 \\
\hline 1964 & 7873 & 89 \\
\hline 1965 & 7551 & 85 \\
\hline
\end{tabular}

Примечание. Таблицы 1 и 2 составлены автором статьи. 
9, л. $2 ; 15$, л. $3 ; 16$, л. $133 ; 17$, л. $5 ; 18$, л. $84 ; 27$, с. 398-399].

Активное закрытие храмов начинается в 1960 году. Уполномоченный Совета по Краснодарскому краю С.Ф. Бабушкин проводил свою работу в 1960 г. на основе постановления ЦК КПСС от 13 января 1960 г. «О мерах по ликвидации нарушений духовенством советского законодательства о культах» $[6$, л. 26]. Этот документ коренным образом изменил направление в работе уполномоченных по наблюдению за деятельностью церкви. Теперь Уполномоченный мог не только наблюдать и регистрировать церковные события, но и активно влиять на церковную жизнь. Уполномоченный Совета по Краснодарскому краю неоднократно беседовал с архиепископом Виктором (Святиным) и членами епархиального совета о сокращении количества благочиний в Краснодарской и Кубанской епархии. В результате 11 ноября 1960 г. циркулярным распоряжением архиепископа Виктора (Святина) по епархии были упразднены 11 благочиний из 23 и все церковные приходы объединились в 12 благочиний [6, л. 28]. Руководство епархии было вынуждено пойти на этот шаг. Следует отметить, что с 1956 по 1966 г. Краснодарскую и Кубанскую епархию возглавлял архиепископ Виктор (Святин) (с 1961 г. митрополит). Как отмечал Уполномоченный Совета по Краснодарскому краю С.Ф. Бабушкин: «архиепископ Виктор стремится внешне и внутренне благоустраивать церкви и молитвенные дома, внедряет в каждый приход хоровое церковное пение, наводит дисциплину и требует от духовенства благопристойного поведения» $[6$, л. 21]. Таким образом, в этот сложный для Церкви период архиепископ Виктор (Святин) последовательно проводил линию на укрепление позиций РПЦ в крае.

Максимальное число закрытых церквей и молитвенных домов в Краснодарском крае пришлось на 1961 г. и 1962 г. - соответственно 32 и 31 храм (табл. 1). Всего за 7 лет (19581964 гг.) количество церквей и молитвенных домов в Краснодарском крае сократилось на $59 \%$. В масштабах всей страны сокращение произошло на 44 \%. Таким образом, в исследуемом регионе было закрыто храмов на $15 \%$ больше, чем по СССР в целом.
Летом 1961 г. разворачивается кампания по учету религиозных объединений, молитвенных домов и имущества, находящегося в пользовании церковными органами. Власти считали, что у РПЦ слишком большое количество храмов. Новый Председатель Совета по делам Русской православной церкви при Совете Министров СССР В.А. Куроедов в своем докладе на Всесоюзном совещании уполномоченных Совета в апреле 1960 г. ориентировал уполномоченных на сокращение численности храмов: «...у нас в ряде областей и республик имеется слишком большая сеть церковных учреждений, не вызываемая никакой практической надобностью...» [26, c. 86]. Совет рекомендовал уполномоченным решать проблему сокращения количества приходов с ликвидации «затухающих приходов», экономически слабых и не поддерживаемых населением. В своем докладе 18 марта 1961 г. Председателю Совета по делам Русской православной церкви при Совете Министров СССР В.А. Куроедову Уполномоченный по Краснодарскому краю сообщал, что планирует в 1961 г. закрыть 40 таких приходов, в 1962 г. - 30 приходов [6, л. 36]. Данные, представленные в таблице 1 , подтверждают почти полное выполнение этого плана. Закрытие молитвенных зданий происходило, если несколько приходов объединялись, если приход был снят с регистрации, если здание подлежало сносу вследствие его ветхости.

Резкое уменьшение количества храмов также было следствием принятия 16 марта 1961 г. закрытого постановления Советом Министров СССР «Об усилении контроля за выполнением законодательства о культах» [21, л. 79]. Одним из пунктов данного постановления было разрешение закрывать храмы и молитвенные дома по решениям областных, краевых исполнительных органов власти, но при согласовании с Советом по делам РПЦ. Это облегчало процесс закрытия храмов. В марте 1961 г. Исполнительный комитет Краснодарского краевого Совета депутатов трудящихся принял постановление «О наведении порядка в деятельности религиозных групп и объединений верующих граждан». Этот документ давал право горисполкомам, райисполкомам и сельским советам налагать штрафы и привлекать к исправительным ра- 
ботам лиц, нарушающих советское законодательство о культах [23, л. 82]. Таким образом, местные органы власти получили широкие полномочия по контролю над религиозными организациями и священнослужителями.

31 марта 1961 г. В.А. Куроедов заявил руководству Патриархата о необходимости проведения «церковной реформы», целью которой было отстранение священнослужителей от руководства приходами [27, с. 379]. Суть реформы заключалась в следующем - возглавлять общину должен приходской совет исполнительный орган, которому передавалась вся финансовая и хозяйственная деятельность, на него же возлагалась ответственность перед гражданской властью за сохранность здания и имущества храма. Священнослужители становились нанимаемыми общиной по трудовому договору людьми, которые в связи со своим статусом не допускались на выборное собрание церковного совета. 18 июля 1961 г. в Троице-Сергиевой Лавре состоялся Архиерейский Собор, который установил новую организацию приходского управления [27, с. 379]. Реформа приходского управления была принята под жестким нажимом властей и была вынужденной мерой для РПЦ.

В результате данной реформы настоятели приходов отделялись от приходской жизни, лишившись всякой возможности вмешательства в хозяйственные дела общин, оказавшись на положении наемных лиц у церковного совета. Священнослужители переводились с оплаты за требы на твердые оклады. С 1 марта 1962 г. все православное духовенство Краснодарской и Кубанской епархии было переведено на оклады. Размер окладов колебался от 350 до 185 рублей [16, л. 19]. Через приходские исполнительные органы контролировались финансовые поступления в приходы. Для этого вводились квитанционные книжки. Оформление квитанций было обязанностью членов церковного совета, а не духовенства. В православных храмах Краснодарского края с 1 июля 1962 г. введен реестр на оплату за отправление религиозных треб верующих [16, л. 19]. Реестр заполнялся на каждую требу в двух экземплярах. Один оставался в делах церковного органа, второй выдавался на руки верующим для передачи священнику, исполняющему требу. Таким образом, был установ- лен жесткий контроль за количеством совершенных треб.

В случае если священнослужители продолжали вмешиваться в хозяйственную деятельность прихода, они снимались с регистрации Уполномоченным Совета по делам РПЦ за нарушение советского законодательства о культах. По данным Уполномоченного Совета по Краснодарскому краю С.Ф. Бабушкина, в течение 1962 г. в исследуемом регионе за вмешательство в финансово-хозяйственную деятельность было снято с регистрации 28 священнослужителей [16, л. 100].

В связи с реформой власть епархиального архиерея (патриарха) минимизировалась до такой степени, что регистрация священника на приходе зависела от Уполномоченного Совета и от приходского исполнительного органа. По мнению Д.В. Поспеловского, приходская реформа привела к установлению над приходами и епархиями диктатуры уполномоченных Совета по делам Русской православной церкви и местных государственных органов власти - исполкомов [20, с. 95].

Новая государственная религиозная политика привела к сокращению православного духовенства (табл. 2) [6, л. 38; 8, л. 54; 9, л. $3 ; 15$, л. $5 ; 16$, л. $134 ; 17$, л. $23 ; 18$, л. $84 ; 27$, с. $398-399]$.

Как видно из таблицы 2 , на 1 января 1958 г. в Краснодарском крае было зарегистрировано 260 священнослужителей. В целом за 1958-1964 гг. количество священнослужителей сократилось с 243 до 111 человек, или на $54,3 \%$, что на $18,4 \%$ больше, чем в масштабах всей страны. Наибольшее сокращение на 35 человек произошло в 1961 году. К причинам снижения численности зарегистрированного православного духовенства в регионе можно отнести, прежде всего, закрытие действующих церквей и молитвенных домов, нарушение священнослужителями советского законодательства о культах, если выбыли из епархии, а также естественная смерть.

После принятия постановления ЦК КПСС от 13 января 1960 г. «О мерах по ликвидации нарушений духовенством советского законодательства о культах» в регионах ужесточился контроль за священнослужителями. В Краснодарском крае в 1960 г. количество священнослужителей сократилось на 25 человек, 7 из которых были сняты с регис- 
Таблица 2. Статистические данные о количестве священнослужителей РПЦ (1956-1965 гг.)

Table 2. Statistics on the number of the clergy of the Russian Orthodox Church (1956-1965)

\begin{tabular}{|c|c|c|}
\hline \multirow{2}{*}{ Год } & Количество священнослужителей на 1 января, чел. \\
\cline { 2 - 3 } & в СССР & в Краснодарском крае \\
\hline 1956 & 12250 & 242 \\
\hline 1957 & - & 235 \\
\hline 1958 & 12169 & 260 \\
\hline 1959 & 11980 & 243 \\
\hline 1960 & 11407 & 222 \\
\hline 1961 & 9061 & 197 \\
\hline 1962 & 9269 & 162 \\
\hline 1963 & 8057 & 131 \\
\hline 1964 & 7673 & 117 \\
\hline 1965 & - & 111 \\
\hline
\end{tabular}

трации Уполномоченным. Этих священнослужителей обвинили в «нарушении советского законодательства о культах». К нарушениям были отнесены: благотворительная деятельность духовенства, исполнение религиозных обрядов за пределами своего прихода, организация общественных обедов в храмовые праздники [6, л. 38]. Органы власти наказывали священнослужителей за деятельность, которая всегда была составной частью жизни РПЦ.

Следует отметить, что к обеспечению контроля за выполнением законодательства о культах привлекались не только местные органы власти. При исполкомах на местах стали создаваться комиссии содействия по наблюдению за выполнением законодательства о культах. В Краснодарском крае в январе 1961 г. при горисполкомах и райисполкомах были организованы общественные группы содействия по наблюдению за деятельностью церкви и духовенства. В состав группы входило по 5-7 человек на каждый молитвенный дом или церковь. Группы создавались на общественных началах, под руководством членов исполкомов, ведающих вопросами культов [10, л. 2]. В 1963 г. во всех городах, районах и большинстве сельских Советов Краснодарского края были образованы общественные комиссии содействия, призванные помогать исполкомам в проведении мероприятий по усилению контроля за выполнением советского законодательства о культах. В состав комиссий входили депутаты местных Советов, работники финансовых органов, органов народного образования, врачи. На 1 января 1965 г. в Краснодарском крае насчитывалось
95 комиссий, в которые входило 874 человека $[15$, л. 8]. Комиссии анализировали религиозную обстановку в своем регионе, изучали данные о религиозных обрядах, проводили беседы с родителями окрестивших детей, выявляли нарушения законодательства религиозными организациями и священнослужителями. Таким образом, к реализации государственной религиозной политики были привлечены не только местные органы власти, но и общественность, что способствовало широкомасштабному наступлению на РПЦ.

Несмотря на закрытие храмов и уменьшение количества священнослужителей религиозная жизнь в исследуемом регионе не замирала. Важным показателем религиозности населения, будь она глубоко осознанная или проявляющаяся в силу традиций, является совершение религиозных обрядов и различных треб. В 1958 г., по сравнению с предыдущим годом, в приходах Краснодарского края наблюдалось уменьшение некоторых количественных показателей: число крещений уменьшилось с 21847 до 20 222, при этом количество рождений увеличилось с 69428 до 71952 , венчаний - с 1428 до 1419 при увеличении количества зарегистрированных браков с 40811 до 47 406, отпеваний - с 7400 до 7194 при уменьшении числа умерших по сведениям ЗАГС с 26917 до 25636 [9, л. 31]. Таким образом, небольшое уменьшение количества совершенных обрядов наблюдалось до начала административного натиска государственных органов власти на религиозные организации. С 1958 по 1964 г. количество крещений уменьшилось на 38,2 \% (с 20222 до 12 508), венчаний - на 87 \% (с 1419 до 184), 
отпеваний - на 66 \% (с 7194 до 2 447) [9, л. 31; 15, л. 21-23]. Большую часть граждан, принявших крещение, составляли младенцы, также крестили детей школьного возраста и взрослых. Обряд крещения составлял наибольшую часть в общем количестве совершенных обрядов. Всего за 1958-1964 гг. было совершено: крещений - 146 403, венчаний 4 464, похорон по церковному обряду - 52020. Следует отметить, что в Краснодарском крае в 1962 г. количество крещений увеличилось по сравнению с предыдущим годом с 19945 до 29 892. И при этом уполномоченный Совета в своих отчетах постоянно указывал: «данные о совершенных обрядах духовенство занижает» $[16$, л. 115]. Такой рост количества крещений не устраивал местные власти.

Чтобы уменьшить количество совершаемых религиозных обрядов, с 1 июля 1962 г. для обряда крещения был введен новый порядок оформления документов [11, л. 92]. Крестить детей разрешалось только с согласия обоих родителей, и записывать имя, отчество, фамилию и место жительства родителей. В подтверждение своих прав на ребенка родители должны были предъявлять документ, удостоверяющий их личность (паспорт или удостоверение для непаспортизированных). Советские органы власти были уверены, что установленный порядок приведет к значительному снижению количества крещений. Однако даже после введения нового порядка в отдельных районах Краснодарского края процент крещеных детей к числу рожденных оставался высоким. Например, за июль, август, сентябрь 1962 г. он составил в Белоглинском районе - $100 \%$, Усть-Лабинском - $90 \%$, Приморско-Ахтарском - 85,5 \%, Кущевском 83,5 \%, городе Ейске - 79 \%, Красноармейском - $75 \%$, Темрюкском - $74 \%$ [11, л. 93]. В борьбе с религиозностью населения местные власти зачастую допускали нарушения прав верующих. В июне 1964 г. в селах и станицах Краснодарского края был усложнен порядок оформления документов на крещение детей, согласно которому родители должны были подавать заявление в церковный исполнительный орган с просьбой окрестить ребенка, а их подписи на заявлении должны быть заверены сельским или районным исполкомами. Несколько позднее такой же порядок ме- стные власти ввели в следующих городах: Армавире, Кропоткине, Тихорецке и Майкопе. В остальных городах края крещение детей проводилось без каких-либо заявлений. После введения подачи заявлений на крещение детей некоторые райисполкомы и многие сельские советы стали на путь администрирования и отказа заверять подписи родителей, что вызвало потоки жалоб и заявлений верующих не только в церковные органы, но и различные советские организации. Столкнувшись с недовольством верующих, Уполномоченный Совета по делам РПЦ по Краснодарскому краю в январе 1965 г. рекомендовал отменить заверение подписей на заявлениях [24, л. 82]. Таким образом, верующие Краснодарского края, как могли, сопротивлялись новой религиозной политике.

Ликвидировать религиозные обряды административным путем органам власти не удалось. Поэтому в 1962 г. было разработано новое направление в антирелигиозной кампании. ЦК КПСС ориентировал партийные и советские органы на борьбу с религиозными традициями путем вытеснения их новыми праздниками. Предлагалось организовывать новые нерелигиозные обряды. Венчание должна вытеснить советская свадьба, в противовес крестинам организовывать советские октябрины.

Начало этому направлению работы положила Всесоюзная конференция по научноатеистической пропаганде, проходившая в феврале 1962 года [27, с. 384]. На конференции было озвучено мнение, что религиозные обычаи и традиции следует вытеснять новыми праздниками и ритуалами для удовлетворения эстетических и эмоциональных потребностей верующих. В августе 1962 г. соответствующее решение приняло бюро ЦК КПСС по РСФСР $[27$, с. 384$]$. Ввиду этого в начале 1963 г. по инициативе партийных и советских органов в Краснодарском крае было положено начало проведению торжественной гражданской регистрации новорожденных. Первыми организаторами этого праздника выступили Ново-Титаровский и Марьянский сельские советы Динского района. Крайисполком одобрил подобную инициативу и рекомендовал всем горрайисполкомам принять меры к распространению такого опыта. В июле 1963 г. был раз- 
работан примерный ритуал торжественной регистрации брака и применен на практике 4 августа 1963 г. в городе Славянск-на-Кубани. В 1963 г. в крае было проведено 1458 торжественно-гражданских регистраций новорожденных с применением нового ритуала. Зарегистрировано 4000 детей и более 400 торжественных гражданских регистраций брака, зарегистрировавших 2563 пары молодоженов. Организаторами гражданских регистраций в крае выступали, кроме райисполкомов, их отделов ЗАГС, отделов культуры, городских, сельских и поселковых советов, так же общественные советы по гражданским обрядам, образованные при горрайисполкомах в начале 1963 года. В Краснодарском крае к 1 января 1964 г. были организованы 81 общественный совет [17, л. 12]. Однако введение новых гражданских традиций не смогло вытеснить из жизни верующих традиционные религиозные обряды. Так, в 1963 г. в крае было зарегистрировано 67000 рождений детей, крещений детей зарегистрировано 24 350, или $36 \%$ к общему числу родившихся. Продолжалась традиция венчания и отпевания. Здесь цифры несколько меньше: зарегистрировано браков 34823 , из них венчаний -233 , или $0,6 \%$ от общего количества регистраций, зарегистрировано смертей 31 222, из них совершено отпеваний 8 333, или 26,6 \% [17, л. 14]. Подобная статистика прослеживается и в 1964 году. Таким образом, религиозная политика советской власти не смогла кардинально повлиять на состояние религиозности населения Краснодарского края. Местные власти объясняли это слабой научно-атеистической пропагандой, проводимой в регионе. Однако следует отметить, что сохранению религиозности населения в крае способствовали и многовековые православные традиции.

Результаты. В 1958-1964 гг. религиозная политика в отношении РПЦ носила антицерковный характер. В Краснодарском крае она осуществлялась через местные партийные, советские и общественные организации. Действия партийных и советских органов власти были направлены на вытеснение РПЦ из жизни советских граждан и государства в целом. Антирелигиозная политика государства сказалась на деятельности каждого православного прихода Краснодарской и Кубанской епархии. В Краснодарском крае РПЦ подверглась сильнейшей атаке со стороны местных органов власти. В результате антицерковных кампаний было закрыто более половины храмов и молитвенных домов, кадровый состав священнослужителей сократился на 54,3\%. Для искоренения религиозных традиций местные органы власти вводили новый порядок оформления документов для крещения, организовывали торжественную гражданскую регистрацию новорожденных, советские свадьбы. Несмотря на это реализация религиозной политики не привела к искоренению религиозности в сознании жителей исследуемого региона.

\section{СПИСОК ЛИТЕРАТУРЫ}

1. Алексеев, В. А. Иллюзии и догмы / В. А. Алексеев. - М. : Политиздат, 1991.-398 с.

2. Бабич, А. В. Православные приходы Советской Кубани / А. В. Бабич, С. Н. Рыбко // Дело мира и любви. Очерки истории и культуры православия на Кубани / под ред. О. В. Матвеева. - Краснодар : Православный Екатеринодар : Традиция, 2009. C. $155-174$.

3. Барменков, А. Н. Свобода совести в СССР / А. Н. Барменков. - М. : Мысль, 1979. - 223 с.

4. Гордиенко, Н. С. Эволюция русского православия (20-80-е гг. XX столетия) / Н. С. Гордиенко. - М. : Знание, 1984. -64 с.

5. Гордун, С., свящ. Русская православная церковь в период с 1943 по 1970 год / С. Гордун, свящ. // Журнал Московской Патриархии. - 1993. № 1. - C. 39-49; № 2. - C. 11-24.

6. Доклад «О работе уполномоченного Совета по делам Русской православной церкви при Совете Министров СССР по Краснодарскому краю за 1960 год», 18 марта 1961 года // Центр документации новейшей истории Краснодарского края (ЦДНИКК). - Ф. 1774-А. - Оп. 9. - Д. 158. - Л. 20-43.

7. Законодательство о религиозных культах / под ред. В. А. Куроедова. - М. : Юрид. лит., 1971. $-210 \mathrm{c}$.

8. Информационный отчет от 10 ноября 1958 г. «О работе уполномоченного Совета по делам Русской православной церкви при Совете Министров СССР по Краснодарскому краю за $1957-$ 1958 гг.» // ЦДНИКК. - Ф. 1774-А. - Оп. 6. - Д. 185.Л. $22-120$.

9. Информационный отчет от 21 января 1960 г. «О работе уполномоченного Совета по делам Русской православной церкви при Совете Ми- 
нистров СССР по Краснодарскому краю за 1959 год» // ЦДНИКК. - Ф. 1774-А. - Оп 8. - Д. 163. - Л. 2-33.

10. Информационное письмо заместителя председателя Краснодарского краевого исполнительного комитета от 23 января 1961 г. «Об организации общественных групп содействия, в целях усиления наблюдения за деятельностью служителей религиозных культов в Краснодарском крае» // Государственный архив Краснодарского края (ГАКК). - Ф. Р-1519. - Оп. 2. - Д. 16. - Л. 2-7.

11. Информационное сообщение уполномоченного Совета по делам Русской православной церкви при Совете Министров СССР по Краснодарскому краю от 23 ноября 1962 г. «Об исполнении обряда крещения по молитвенным домам Краснодарской епархии за 1962 год» // ЦДНИКК. Ф. 1774-А. -Оп. 10. - Д. 152. - Л. 92-94.

12 Кринко, Е. Ф. Православная церковь на Кубани в годы Великой Отечественной войны / Е. Ф. Кринко // Дело мира и любви. Очерки истории и культуры православия на Кубани / под ред. О. В. Матвеева. - Краснодар : Православный Екатеринодар : Традиция, 2009. - С. 144-154.

13. Куроедов, В. А. Религия и церковь в Советском государстве / В. А. Куроедов. - М. : Политиздат, 1980. $-263 \mathrm{c}$

14. Одинцов, М. И. Государство и церковь в России, ХХ век / М. И. Одинцов. - М. : Луч, 1994. $172 \mathrm{c}$.

15. Отчет «О работе уполномоченного Советов по делам Русской православной церкви и религиозных культов при Совете Министров СССР по Краснодарскому краю за 1964 год» от 27 февраля 1965 года // ГАКК. - Ф. Р-1519. - ОП. 2. - Д. 49. Л. 3-37.

16. Отчет «О работе уполномоченного Совета по делам Русской православной церкви при Совете Министров СССР по Краснодарскому краю за 1962 год» от 12 февраля 1963 года // ГАКК. - Ф. Р-1519. - Оп. 2. - Д. 23. - Л. 19-134.

17. Отчет «О работе уполномоченного Совета по делам Русской православной церкви при Краснодарском промышленном и сельском крайисполкомах за 1963 год» от 10 февраля 1964 года // ГАКК. Ф. Р-1519. - Оп. 2. - Д. 34. - Л. 4-41.

18. Отчет «О работе уполномоченного Совета по делам Русской православной церкви при Совете Министров СССР по Краснодарскому краю за первое полугодие 1956 года» от 20 июля 1956 года // ЦДНИКК. - Ф. 1774-А. - Оп. 4а. Д. 153. - Л. 37-101.

19. Панков, Г. Д. О политике Советского государства в отношении к Русской православной церкви на рубеже 50-60-х годов / Г. Д. Панков // Религия и демократия: на пути к свободе совести. Вып. II. М. : Прогресс-Культура, 1993. - С. 217-231.
20. Поспеловский, Д. В. Русская православная церковь в XX веке / Д. В. Поспеловский. - М. : Республика, 1995. $-511 \mathrm{c}$.

21. Постановление Совета Министров СССР от 16 марта 1961 г. № 263 «Об усилении контроля за выполнением законодательства о культах» // ГАКК. Ф. Р-1519. - Оп. 2. - Д. 16. - Л. 74-80.

22. Соколова, М. И. Советское государство и Русская православная церковь в 1953-1964 гг: на материалах Сталинградской (Волгоградской) области : дис. .... канд. ист. наук : 070002 / Соколова Мария Игоревна. - Волгоград, 2016. - 357 с.

23. Справка к докладу уполномоченного Coвета по делам Русской православной церкви по Краснодарскому краю от 14 апреля 1961 г. «О ходе выполнения решения ЦК КПСС от 13 января 1960 года» // ГАКК. - Ф. Р-1519. - Оп. 2. - Д. 16. Л. 81-84.

24. Справка уполномоченного Совета по делам Русской православной церкви по Краснодарскому краю от 6 января 1965 г. «О введении нового порядка оформления документов на крещение детей в селах и станицах Краснодарского края» // ГАКК. -Ф. Р-1519. Оп. 2. - Д. 49. - Л. 78-83.

25. Трегубенко, В. В. Религиозный вопрос на Ставрополье и Кубани в 1941 г. - начале 1960-х гг.: сущность, место в обществе, отношение власти : дис. ... канд. ист. наук : 07.00.02 / Трегубенко Владимир Владимирович. - Ростов н/Д, 2013. - 223 с.

26. Чумаченко, Т. А. Государство и Русская православная церковь в 1958-1964 гг.: новая политическая война с религией, церковью и верующими / Т. А. Чумаченко // Вестник Челябинского государственного университета. - 2014. - № 19. C. $82-90$.

27. Шкаровский, М. В. Русская православная церковь при Сталине и Хрущеве (государственноцерковные отношения в СССР в 1939-1964 гг.) / М. В. Шкаровский. - М. : Крутицкое Патриаршее Подворье, 1999. - 400 с.

\section{REFERENCES}

1. Alekseev V.A. Illyuzii i dogmy [Illusions and Dogmas]. Moscow, Politizdat, 1991.398 p.

2. Babich A.V., Rybko S.N. Pravoslavnye prikhody Sovetskoy Kubani [Orthodox Parishes of the Soviet Kuban]. Delo mira i lyubvi. Ocherki istorii $i$ kultury pravoslaviya na Kubani [Deal World and Love. Essays on the History and Culture of Orthodoxy in the Kuban], Krasnodar, Pravoslavnyy Ekaterinodar Publ.; Traditsiya Publ., 2009, pp. 155-174.

3. Barmenkov A.N. Svoboda sovesti v SSSR [Freedom of Conscience in the USSR]. Moscow, Mysl Publ., 1979. 223 p. 
4. Gordienko N.S. Evolyutsiya russkogo pravoslaviya (20-80-e gg. XX stoletiya) [Evolution of Russian Orthodoxy (20s-80s of the $20^{\text {th }}$ Century)]. Moscow, Znaniye Publ., 1984. 64 p.

5. Gordun S. Russkaya pravoslavnaya tserkov v period s 1943 po 1970 god [Russian Orthodox Church from 1943 to 1970]. Zhurnal Moskovskoy Patriarkhii, 1993, no. 1, pp. 39-49; no. 2, pp. 11-24.

6. Doklad «O rabote upolnomochennogo Soveta po delam Russkoy pravoslavnoy tserkvi pri Sovete Ministrov SSSR po Krasnodarskomu krayu za 1960 god», 18 marta 1961 goda [Report "On the Work of the Authorized Council for the Russian Orthodox Church at the Council of Ministers of the USSR for Krasnodar Krai in 1960" for March 18, 1961]. Tsentr dokumentatsii noveyshey istorii Krasnodarskogo kraya (TsDNIKK) [Documentation Centre of Modern History of Krasnodar Krai], F. 1774-A, Op. 9, D. 158, 11. 20-43.

7. Kuroedov V.A., ed. Zakonodatelstvo o religioznykh kultakh [Legislation on Religious Cults]. Moscow, Yurid. lit. Publ., 1971.210 p.

8. Informatsionnyy otchet ot 10 noyabrya $1958 \mathrm{~g}$. «O rabote upolnomochennogo Soveta po delam Russkoy pravoslavnoy tserkvi pri Sovete Ministrov SSSR po Krasnodarskomu krayu za 1957-1958 gg.» [Information Report on November 10, 1958 «On the Work of the Authorized Council for the Russian Orthodox Church at the Council of Ministers of the USSR in Krasnodar Krai for 1957-1958»]. TSDNIKK [Documentation Centre of Modern History of Krasnodar Krai], F. 1774-A, Op. 6, D. 185, 11. 22-120.

9. Informatsionnyy otchet ot 21 yanvarya $1960 \mathrm{~g}$. «O rabote upolnomochennogo Soveta po delam Russkoy pravoslavnoy tserkvi pri Sovete Ministrov SSSR po Krasnodarskomu krayu za 1959 god» [Information Report of 21 January 1960 «On the Work of the Authorized Council for the Affairs of the Russian Orthodox Church at the Council of Ministers of the USSR for Krasnodar Krai in 1959»]. TsDNIKK [Documentation Centre of Modern History of Krasnodar Krai], F. 1774-A, Op. 8, D. 163, 11. 2-33.

10. Informatsionnoye pismo zamestitelya predsedatelya Krasnodarskogo krayevogo ispolnitelnogo komiteta ot 23 yanvarya $1961 \mathrm{~g}$. «Ob organizatsii obshchestvennykh grupp sodeystviya, $\mathrm{v}$ tselyakh usileniya nablyudeniya za deyatelnostyu sluzhiteley religioznykh kultov v Krasnodarskom krae» [Information Letter of Deputy Chairman of the Krasnodar Krai Executive Committee of January 23, 1961 «About the Organization of Public Groups of Assistance, in Order to Strengthen the Monitoring of the Activities of Religious Ministers in Krasnodar Krai»]. Gosudarstvennyy arkhiv Krasnodarskogo kraya (GAKK) [State Archive of Krasnodar Krai], F. R-1519, Op. 2, D. 16, 11. 2-7.
11. Informatsionnoe

soobshchenie upolnomochennogo Soveta po delam Russkoy pravoslavnoy tserkvi pri Sovete Ministrov SSSR po Krasnodarskomu krayu ot 23 noyabrya 1962 g. «Ob ispolnenii obryada kreshcheniya po molitvennym domam Krasnodarskoy eparkhii za 1962 god» [Information Message of Commissioner of the Council for the Affairs of the Russian Orthodox Church at the Council of Ministers of the USSR for Krasnodar Krai of November 23, 1962 "On the Performance of the Rite of Baptism at Prayer Houses of the Krasnodar Diocese for 1962"]. TsDNIKK [Documentation Centre of Modern History of Krasnodar Krai], F. 1774-A, Op. 10, D. $152,11.92-94$.

12. Krinko E.F. Pravoslavnaya tserkov na Kubani v gody Velikoy Otechestvennoy voyny [The Orthodox Church in Kuban During the Great Patriotic War]. Matveyeva O.V., ed. Delo mira i lyubvi. Ocherki istorii i kultury pravoslaviya na Kubani [Deal of World and Love. Essays on the History and Culture of Orthodoxy in the Kuban]. Krasnodar, Pravoslavnyy Ekaterinodar Publ.; Traditsiya Publ., 2009, pp. 144-154.

13. Kuroedov V.A. Religiya i tserkov v Sovetskom gosudarstve [Religion and Church in the Soviet State]. Moscow, Politizdat, 1980. 263 p.

14. Odintsov M.I. Gosudarstvo i tserkovv Rossii. $X X$ vek [State and Church in Russia. $20^{\text {th }}$ Century]. Moscow, Luch Publ., 1994. 172 p.

15. Otchet $« \mathrm{O}$ rabote upolnomochennogo Sovetov po delam Russkoy pravoslavnoy tserkvi i religioznykh kultov pri Sovete Ministrov SSSR po Krasnodarskomu krayu za 1964 god» ot 27 fevralya 1965 goda [Report "On the Work of the Authorized Councils for the Russian Orthodox Church and Religious Cults at the Council of Ministers of the USSR in Krasnodar Krai in 1964" on February 27, 1965]. GAKK [State Archive of Krasnodar Krai], F. R-1519, Op. 2, D. 49, 11. 3-37.

16. Otchet «O rabote upolnomochennogo Soveta po delam Russkoy pravoslavnoy tserkvi pri Sovete Ministrov SSSR po Krasnodarskomu krayu za 1962 god» ot 12 fevralya 1963 goda [Report "On the Work of the Authorized Council for the Russian Orthodox Church at the Council of Ministers of the USSR for Krasnodar Krai in 1962" on 12 February 1963]. GAKK [State Archive of Krasnodar Krai], F. R-1519, Op. 2, D. 23, 11. 19-134.

17. Otchet «O rabote upolnomochennogo Soveta po delam Russkoy pravoslavnoy tserkvi pri Krasnodarskom promyshlennom i selskom krayispolkomakh za 1963 god» ot 10 fevralya 1964 goda [Report "On the Work of the Authorized Council for the Russian Orthodox Church at the Krasnodar Industrial and Rural Executive Committees for 1963" on February 10, 1964]. GAKK [State Archive of Krasnodar Krai], F. R-1519, Op. 2, D. 34, 11. 4-41. 
18. Otchet «O rabote upolnomochennogo Soveta po delam Russkoy pravoslavnoy tserkvi pri Sovete Ministrov SSSR po Krasnodarskomu krayu za pervoe polugodie 1956 goda» ot 20 iyulya 1956 goda [Report "On the Work of the Authorized Council for the Russian Orthodox Church Under the Council of Ministers of the USSR for Krasnodar Krai for the First Half of 1956" Dated July 20, 1956]. TsDNIKK [Documentation Centre of Modern History of Krasnodar Krai], F. 1774-A, Op. 4a, D. 153, 11. 37-101.

19. Pankov G.D. O politike Sovetskogo gosudarstva $\mathrm{v}$ otnoshenii k Russkoy pravoslavnoy tserkvi na rubezhe 50-60-kh godov [The Soviet State in Relation to the Russian Orthodox Church at the Turn of 50s-60s]. Religiya i demokratiya: na puti $k$ svobode sovesti [Religion and Democracy: On the Way to Freedom of Conscience]. Vol. 2. Moscow, ProgressKultura Publ., 1993, pp. 217-231.

20. Pospelovskiy D.V. Russkaya pravoslavnaya tserkov $v X X$ veke [Russian Orthodox Church in the $20^{\text {th }}$ Century]. Moscow, Respublika Publ., 1995. 511 p.

21. Postanovlenie Soveta Ministrov SSSR ot 16 marta 1961 g. № 263 «Ob usilenii kontrolya za vypolneniyem zakonodatelstva o kultakh» [Resolution of the Council of Ministers of the USSR of March 16, 1961 no. 263 "On Strengthening Control Over the Implementation of Legislation on Cults"]. GAKK [State Archive of Krasnodar Krai], F. R-1519, Op. 2, D. 16, 11. $74-80$.

22. Sokolova M.I. Sovetskoe gosudarstvo $i$ Russkaya pravoslavnaya tserkov v 1953-1964 gg.: na materialakh Stalingradskoy (Volgogradskoy) oblasti: dis. ... kand. ist. nauk: 070002 [Soviet State and Russian Orthodox Church in 1953-1964 (Based on the Materials of the Stalingrad (Volgograd) Region). Cand. Hist. Sci. Diss.]. Volgograd, 2016. 357 p.

23. Spravka k dokladu upolnomochennogo Soveta po delam Russkoy pravoslavnoy tserkvi po Krasnodarskomu krayu ot 14 aprelya 1961 g. «O khode vypolneniya resheniya TsK KPSS ot 13 yanvarya
1960 goda» [Reference to the Report of the Authorized Council for the Russian Orthodox Church in Krasnodar Krai of April 14, 1961 "On the Implementation of the Decision of the CPSU Central Committee of January 13, 1960"]. GAKK [State Archive of Krasnodar Krai], F. R-1519, Op. 2, D. 16, 11. 81-84.

24. Spravka upolnomochennogo Soveta po delam Russkoy pravoslavnoy tserkvi po Krasnodarskomu krayu ot 6 yanvarya $1965 \mathrm{~g}$. «O vvedenii novogo poryadka oformleniya dokumentov na kreshchenie detey v selakh i stanitsakh Krasnodarskogo kraya» [Reference of the Authorized Council for the Russian Orthodox Church in Krasnodar Krai of January 6, 1965 "On the Introduction of a New Procedure for Processing Documents for the Baptism of Children in the Villages and Villages of Krasnodar Krai'"]. GAKK [State Archive of Krasnodar Krai], F. R-1519, Op. 2, D. 49, 11. 78-83.

25. Tregubenko V.V. Religioznyy vopros na Stavropolye i Kubani v 1941 g. - nachale 1960-kh gg.: sushchnost, mesto vobshchestve, otnoshenie vlasti: dis. ... kand. ist. nauk: 07.00.02 [The Religious Issue in Stavropol Krai and Kuban in 1941 - Early 1960s: Nature, Place in Society, the Attitude of the Authorities. Cand. Hist. Sci. Diss.]. Rostov-on-Don, 2013. 223 p.

26. Chumachenko T.A. Gosudarstvo i Russkaya pravoslavnaya tserkov v 1958-1964 gg.: novaya politicheskaya voyna s religiey, tserkovyu i veruyushchimi [The State and The Russian Orthodox Church in 1958-1964: A New Political War with Religion, Church and Believers]. Vestnik Chelyabinskogo gosudarstvennogo universiteta [Bulletin of Chelyabinsk State University], 2014, no. 19, pp. 82-90.

27. Shkarovskiy M.V. Russkaya pravoslavnaya tserkov pri Staline i Khrushcheve (gosudarstvennotserkovnye otnosheniya v SSSR v 1939-1964 gg.) [The Russian Orthodox Church Under Stalin and Khrushchev: State-Church Relations in the USSR in 1939-1964]. Moscow, Krutitskoe Patriarshee Podvorye Publ., 1999. 400 p.

\section{Information about the Author}

Natalia Yu. Belikova, Candidate of Sciences (History), Associate Professor, Department of History and Philosophy, Kuban State Technological University, Moskovskaya St., 2, 350072 Krasnodar, Russian Federation, belikova2003@mail.ru, https://orcid.org/0000-0003-2362-1275

\section{Информация об авторе}

Наталья Юрьевна Беликова, кандидат исторических наук, доцент кафедры истории и философии, Кубанский государственный технологический университет, ул. Московская, 2, 350072 г. Краснодар, Российская Федерация, belikova2003@mail.ru, https://orcid.org/0000-0003-2362-1275 